\title{
Multiorgan Autonomic Dysfunction in Mice Lacking the $\beta 2$ and the $\beta 4$ Subunits of Neuronal Nicotinic Acetylcholine Receptors
}

\author{
Wei Xu, ${ }^{1}$ Avi Orr-Urtreger, ${ }^{6}$ Filippo Nigro, ${ }^{3}$ Shari Gelber, ${ }^{4}$ Cara Ballard Sutcliffe, ${ }^{1}$ Dawna Armstrong, ${ }^{2}$ \\ James W. Patrick, ${ }^{3}$ Lorna W. Role, ${ }^{4,5}$ Arthur L. Beaudet, ${ }^{1}$ and Mariella De Biasi ${ }^{3}$ \\ Departments of ${ }^{1}$ Molecular and Human Genetics and ${ }^{2}$ Pathology and ${ }^{3}$ Division of Neuroscience, Baylor College of \\ Medicine, Houston, Texas, 77030, ${ }^{4}$ Center for Neurobiology and Behavior and ${ }^{5}$ Department of Anatomy and Cell Biology, \\ Columbia University, New York, New York, 10032, and 6The Genetics Institute, Tel-Aviv Sourasky Medical Center, \\ Tel-Aviv, Israel
}

Transcripts for the $\beta 2$ and the $\beta 4$ nicotinic acetylcholine receptor (nAChR) subunits are found throughout the CNS and the peripheral nervous system. These two $\beta$ subunits can form heteromultimeric channels with any of the $\alpha 2, \alpha 3, \alpha 4$, or $\alpha 5$ subunits in heterologous expression systems. Nonetheless, the subunit composition of native nAChRs and the role of different $\mathrm{nAChR}$ subtypes in vivo remain unclear. We prepared null mutations for the $\beta 2$ and the $\beta 4$ genes and bred $\beta 2-/-\beta 4-/-$ mice by mating mice of identical $\beta 2-/-\beta 4+/-$ or $\beta 2+/-\beta 4-/-$ genotype. The $\beta 2-/-$ and the $\beta 4-/-$ singlemutant mice grow to adulthood with no visible phenotypic abnormalities. The $\beta 2-/-\beta 4-/-$ double mutants survive to birth but have impaired growth and increased perinatal mortality. They also present enlarged bladders with dribbling urination and develop urinary infection and bladder stones. The ocular pupils are widely dilated and do not constrict in response to light. Histological studies revealed no significant abnormalities of brain or peripheral tissues except for hyperplasia in the bladder mucosa of $\beta 4-/-$ and $\beta 2-/-\beta 4-/-$ mutants. Bladder strips from $\beta 2-/-\beta 4-/-$ mice did not respond to nicotine but contracted when stimulated with a muscarinic agonist or electric field stimulation. Bladder strips from $\beta 4$ mutants did not respond to nicotine despite the absence of major bladder dysfunction in vivo. Acetylcholine-activated whole-cell currents were absent in superior cervical ganglion neurons from $\beta 2-/-\beta 4-/-$ mice and reduced in neurons from $\beta 4-/-$ mice. Although there is apparent redundancy and a superficially normal phenotype in $\beta 2-/-$ and $\beta 4-/-$ mice, physiological studies indicate major deficits in the $\beta 4-/-$ mice. Our previous description of a similar phenotype in $\alpha 3-/-$ mice and the current data suggest that the $\alpha 3$ and the $\beta 4$ subunits are major components in autonomic nAChRs. The phenotype of the $\beta 2-/-\beta 4-/-$ and $\alpha 3-/-$ mice resembles the autosomal recessive megacystis-microcolon-hypoperistalsis syndrome in humans.

Key words: neuronal nicotinic $\beta$ subunits; autonomic ganglia; autonomic dysfunction; knock-out mice; bladder; eye
Neuronal nicotinic acetylcholine receptors (nAChRs) are expressed throughout the CNS and the peripheral nervous system (PNS) and can be formed by the assembly of both $\alpha$ and $\beta$ subunits (Anand et al., 1991; Cooper et al., 1991; Sargent, 1993; McGehee and Role, 1995). Eleven distinct genes are currently known to encode nAChR subunits, but the composition of native neuronal nAChRs remains undetermined. In heterologous expression systems, the injection of cDNA encoding $\alpha 7, \alpha 8$, or $\alpha 9$ subunits is sufficient to form functional nAChRs alone, whereas the $\alpha 2, \alpha 3$, or $\alpha 4 \mathrm{nAChR}$ subunits require the presence of either $\beta 2$ or $\beta 4$ cDNA for the assembly of functional receptors. The $\alpha 5$, $\alpha 6$, and $\beta 3 \mathrm{nAChR}$ subunits form functional channels only in the presence of other $\alpha$ and $\beta$ subunits (Ramirez-Latorre et al., 1996;

Received June 14, 1999; revised Aug. 12, 1999; accepted Aug. 12, 1999

This work was supported by an American Heart Association Texas affiliate grant to M.D.B., by National Institutes of Health Grants NS-22061 to L.W.R. and NS13546 to J.W.P., and by Mental Retardation Research Center Grant HD-24064. A.L.B. was an investigator in the Howard Hughes Medical Institute during most of the project. We thank Dr. R. A. Lewis for help in characterizing and photographing the ocular findings, Dr. C. N. Ou for performing serum and urine chemistry determinations, and Dr. Y.-H. Yiang, Z. Cheng, and I. Lorenzo, G. Cantrell, L. Goldberg, E. Tam, G. Petruzzi, and B. A. Antalffy for technical assistance.

W.X., A.O.-U., F.N., and S.G. contributed equally to this work.

Correspondence should be addressed to Dr. Mariella De Biasi, Division of Neuroscience, Room S436, Baylor College of Medicine, One Baylor Plaza, Houston, TX 77030. E-mail: debiasi@sensor.bcm.tmc.edu.

Copyright (C) 1999 Society for Neuroscience 0270-6474/99/199298-08\$05.00/0
Wang et al., 1996; Colquhoun and Patrick, 1997; Gerzanich et al., 1997; Fucile et al., 1998).

Each of the 11 genes encoding neuronal nAChRs $(\alpha 2-\alpha 9$ and $\beta 2-\beta 4)$ is expressed in the CNS and PNS, but their relative abundance varies (Listerud et al., 1991; Mandelzys et al., 1994; Rust et al., 1994; Poth et al., 1997). The $\alpha 4$ and the $\beta 2$ genes, although present in the PNS, are highly expressed in several areas of the CNS (Goldman et al., 1987; Morris et al., 1990) and account for $90 \%$ of the high-affinity $\left[{ }^{3} \mathrm{H}\right]$ nicotine-binding sites found in the mammalian brain (Flores et al., 1992; Picciotto et al., 1995). Mice lacking the $\beta 2$ subunit have a superficially normal phenotype but show abnormal passive avoidance and increased neurodegenation on aging (Picciotto et al., 1995; Zoli et al., 1999). Furthermore, the anti-nociceptive effects of nicotine are reduced in both $\alpha 4$ - and $\beta 2$-deficient mice (Marubio et al., 1999).

The $\alpha 3$ subunit is found in the CNS (Wada et al., 1989) but is highly expressed in the PNS (Listerud et al., 1991; Mandelzys et al., 1994; Rust et al., 1994). Recently we demonstrated that mice lacking $\alpha 3$ have several physiological abnormalities including poor growth, decreased survival, absence of bladder contractility, and widely dilated ocular pupils (Xu et al., 1999).

Transcripts for the $\beta 4$ gene are found only in restricted brain regions (Duvoisin et al., 1989; Boulter et al., 1990; Dineley-Miller and Patrick, 1992; Zoli et al., 1998) but are abundantly expressed 
in peripheral neurons (Mandelzys et al., 1994; McGehee and Role, 1995; Poth et al., 1997; Zhang et al., 1998). The concurrent expression of $\beta 2$ and $\beta 4$ in the PNS suggests that $\beta 2$ and $\beta 4$ might be functionally related in the formation of autonomic nAChRs in mammals. However, because the subunit composition of native nAChRs mediating synaptic transmission in the PNS is unknown, the relative contribution of $\beta 2$ - and/or $\beta 4$-containing nAChRs remains elusive. Here we show that mice lacking the $\beta 4$ subunit are superficially normal and grow to adulthood. In contrast, mice lacking both $\beta 2$ and $\beta 4$ have severe autonomic dysfunction, growth retardation, and premature death. Similarly to the $\alpha 3-/-$ mice (Xu et al., 1999), both the $\beta 2-/-\beta 4-/-$ and the $\beta 4-/-$ mutants lack bladder contractile responses to nicotine. In addition, nicotine gated whole-cell currents are absent in the superior cervical ganglion neurons from $\beta 2-/-\beta 4-/-$ mice and are significantly reduced in $\beta 4-/-$ mice. These and previous findings (Xu et al., 1999) suggest that $\alpha 3$ and the $\beta 4$ are requisite participants in the majority of functional ganglionic nAChRs.

\section{MATERIALS AND METHODS}

Targeted deletions of $\beta 2$ and $\beta 4$ genes. The mouse gene for the $\mathrm{nAChR} \beta 2$ subunit was isolated by screening a mouse $129 / \mathrm{SvEv}$ genomic library (a gift from Richard Baehringer; M. D. Anderson Cancer Center, Houston, TX) with a rat cDNA probe (Wada et al., 1989). The isolated genomic clone contained the region from exons 1 to 6 , and the detailed restriction map and intron and exon boundaries were obtained. A construct with the $8 \mathrm{~kb}$ region from exons 1 to 5 , which contains three out of the four transmembrane domains, replaced with a neomycin resistance cassette (Neo) was electroporated into the AB2.1 embryonic stem (ES) cells and transmitted into the germline as described previously (Bradley, 1987; Xu et al., 1999). Chimeric mice were bred with C57BL/6J mice. The mice used in the studies reported here were maintained on the mixed background of $129 / \mathrm{SvEv}$ and C57BL/6J. The mutant allele can be identified as a $6 \mathrm{~kb}$ fragment instead of a $12 \mathrm{~kb}$ fragment on Southern blot analysis using a flanking genomic probe. Three-way PCR with the following primers was also designed to determine the genotype for the mutation: $\beta 2$ wild-type forward, 5'-CTCTGACTGTAAAGGCAGTGGTTGC TATAG-3'; $\beta 2$ wild-type reverse, 5'TAGCTATTGACGACGTCTT TAAGATCC- $3^{\prime}$; and $\beta 2$ mutant reverse, $5^{\prime}$-GAGACTAGTGAGA CGTGCTACTTCCATTTG. The wild-type product is $250 \mathrm{bp}$, and the mutant product is $400 \mathrm{bp}$.

Similarly, screening a mouse $129 / \mathrm{SvJ}$ genomic library (catalog \#946305; Stratagene, La Jolla, CA) with a $\beta 4$ cDNA fragment identified a clone containing the $\beta 4$-coding region (A. Orr-Urtregers, unpublished data). A partial physical map and intron and exon boundaries were determined via subcloning and sequencing. A construct with a $4.1 \mathrm{~kb}$ region containing exon 5 , which encodes for the three transmembrane domains, replaced with a puromycin resistance gene, loxP site, and exons 3-9 of the hypoxanthine phosphorybosyl transferase (hprt) gene (Ramirez-Solis et al., 1995), was electroporated into AB2.2 ES cells. The targeted ES cells were injected into blastocysts and transmitted into the germline (Bradley, 1987; Xu et al., 1999). The $\beta 4$ mutant mice used for the present studies were also maintained in a mixed $129 / \mathrm{SvEv}$ and C57BL/6J background. The mutant allele was identified as a $5.8 \mathrm{~kb}$ fragment instead of a $7.8 \mathrm{~kb}$ one in wild type by the flanking genomic probe when using a SacI digest in Southern blot analysis. The $\beta 4$ null mutation was also identified by three-way PCR with the primer sequences as follows: $\beta 4$ forward, 5'-TGTAGAGCGAGCATCCGAACA-3'; $\beta 4$ wild-type reverse, $5^{\prime}$-TCTCTACTTAGGCTGCCTGTCT; and $\beta 4 \mathrm{mu}-$ tant reverse, 5'-AGTACCTTCTGAGGCGGAAAGA-3'). The wildtype product is $300 \mathrm{bp}$, and the mutant product is $150 \mathrm{bp}$.

The mice with null mutations of both $\beta 2$ and $\beta 4$ subunits were generated via breeding of mice with a single-gene mutation. The expression of $\beta 2$ was assessed by Northern blot analysis of the brain total RNA probed with rat $\beta 2$ cDNA (Wada et al., 1989). The expression of $\beta 4$ was not detectable by Northern blot, but reverse transcription-PCR (RTPCR) was used to test the expression of $\beta 4$. The total RNA from mouse brains was reverse transcribed with random hexamers as primers, and PCR was performed with hprt and $\beta 4$ primers. The sequences of hprt primers were 5'-ATGACCTAGATTTGTTTGTATACC-3' (hprt-1) and 5'-GTAGCTCTTCAGTCTGATAAAATCTAC-3' (hprt-2), and the sequences of $\beta 4$ primers were 5'-GCATCTGGAGAGCGATGACCGA GATCAAAG-3' ( $\beta 4$ RT-1 forward) and 5'-TAGCCTAGGAGTCCTT GGAGGGTGCGTGGA-3' ( $\beta 4$ RT-2 reverse).

Cell culture and whole-cell measurements. Primary cultures of sympathetic neurons were prepared from the superior cervical ganglia of neonatal mice (within $24 \mathrm{hr}$ of birth). Ganglia were removed, desheathed, and cut into pieces in $\mathrm{Ca}^{+2}$ - and $\mathrm{Mg}^{+2}$-free PBS. These pieces were incubated in trypsin $(150 \mu \mathrm{g} / \mathrm{ml}$ type IIIS; Sigma, St. Louis, MO) for 30 min and resuspended in DMEM (Life Technologies, Gaithersburg, MD) supplemented with horse serum $(10 \%)$, penicillin $(50 \mathrm{U} / \mathrm{ml})$, streptomycin $(50 \mu \mathrm{g} / \mathrm{ml})$, glutamine $(2 \mathrm{mM}), 2.5 \mathrm{~S}$ nerve growth factor $(100 \mathrm{ng} / \mathrm{ml}$; Harlan Bioproducts for Science, Madison, WI), and glucose (10 mM). After mechanical dispersion by repeated passage through a fire-polished Pasteur pipette, the ganglion cells were plated on a $0.1 \%$ poly-L-ornithine substrate. To prevent the growth of non-neuronal cells, we supplemented the cultures with $5^{\prime}$-fluorodeoxyuridine (10 $\mu \mathrm{M}$; Sigma) after $2 \mathrm{~d}$. A separate culture was prepared from each pup from litters born to heterozygote parents. Experiments were performed after 5-7 d in culture.

Whole-cell currents were elicited with $300 \mu \mathrm{M}$ nicotine using standard whole-cell techniques. In each experiment, the plating medium was removed, and the neurons were rinsed gently with extracellular recording solution consisting of $150 \mathrm{~mm} \mathrm{NaCl}, 3 \mathrm{mM} \mathrm{KCl}, 2.5 \mathrm{mM} \mathrm{CaCl}_{2}, 10 \mathrm{~mm}$ glucose, $10 \mathrm{~mm}$ HEPES, and $1 \mu \mathrm{M}$ tetrodotoxin, titrated to $\mathrm{pH} 7.2$ with $1 \mathrm{M} \mathrm{NaOH}$. The culture dish was placed on the stage of a Zeiss inverted microscope equipped with phase-contrast optics. Cells were viewed at $400 \times$ with a $40 \times$ objective. All experiments were done at room temperature.

Patch pipettes were pulled from Kimax capillary tubing (Kimble Glass, Vineland, NJ) on a List vertical puller (List, Darmstadt, Germany). Pipette resistances were 2-3 M 2 . The intracellular recording solution consisted of (in mM): $3 \mathrm{NaCl}, 150 \mathrm{KCl}, 1 \mathrm{MgCl}_{2}, 1$ EGTA, 5 MgATP, $0.3 \mathrm{NaGTP}$, and $10 \mathrm{HEPES}$, titrated to $\mathrm{pH} 7.2$ with $1 \mathrm{M} \mathrm{KOH}$. Cells were held at $-60 \mathrm{mV}$, and the series resistance and capacitance compensation were adjusted to eliminate transients. Macroscopic currents were recorded with an Axopatch 200A patch-clamp amplifier (Axon Instruments, Foster City, CA) and a VR-10B analog-to-digital converter (Instrutech Corporation, Great Neck, NY). Currents were acquired and digitally filtered $(1 \mathrm{kHz})$, and the peaks of the currents were detected with Clampex (pClamp6 software; Axon Instruments). Nicotine was dissolved in extracellular recording solution and applied locally by pressure ejection from an $\sim 2 \mu \mathrm{m}$ tip diameter pipette for $5 \mathrm{sec}(12 \mathrm{psi}$; Picospritzer; General Valve, Fairfield, NJ).

Histological, morphological, and physiological analysis. The mice were examined for gross and microscopic pathology. The animals were killed and dissected after fixation in $10 \%$ formalin. Organs were inspected and prepared in blocks. The head and brain were cut in the coronal plane into six blocks. The tissues were dehydrated and impregnated with paraffin, sectioned at $5 \mu \mathrm{m}$, and stained with hematoxylin and eosin (H\&E). The blocks containing the bladder were reacted with anti-neurofilament antibody (anti-neurofilament monoclonal; 1:2000; Dako, Carpinteria, CA) after antigen retrieval in $0.1 \mathrm{M}$ citric acid, $\mathrm{pH}$ 6.0, in the microwave oven three times for $5 \mathrm{~min}$ each. The blocks of head and brain were sectioned at seven levels. One level was prepared with anti-glial fibrillary acidic protein (anti-GFAP; Dako; at 1:1000 dilution). Appropriate controls were used for each study.

To observe the growth and lethality of the mice, we determined the genotype of some newborn mice at birth by PCR. The number and weight of surviving mice were monitored daily to construct growth and survival curves. Blood was drawn from anesthetized mice by cardiac puncture followed by death. Serum was tested for glucose, creatinine, urea nitrogen, $\mathrm{K}^{+}, \mathrm{Na}^{+}, \mathrm{Ca}^{+2}, \mathrm{Cl}^{-}$, and $\mathrm{PO}_{4}{ }^{-3}$. Urine was drawn directly from the bladder of anesthetized mice with a 29 gauge needle syringe and tested for creatinine, glucose, $\mathrm{Na}^{+}, \mathrm{K}^{+}, \mathrm{Ca}^{+2}, \mathrm{PO}_{4}{ }^{-3}$, osmolarity, and bacterial growth. The composition of urinary stones was determined at the Mayo Medical Laboratories (Rochester, MN).

In vitro contractility of mouse urinary bladders. Bladder strips from neonatal mice (2-5 d after birth) were studied as described previously (Xu et al., 1999). Bladder strips were exposed to electrical field stimulation or drugs after a $1 \mathrm{hr}$ equilibration into a Krebs-Henseleit solution aerated with a mixture of $5 \% \mathrm{CO}_{2} / 95 \% \mathrm{O}_{2}$. The Krebs-Henseleit solution had the following composition (in $\mathrm{mM}$ ): $119 \mathrm{NaCl}, 4.7 \mathrm{KCl}, 1.2$ $\mathrm{KH}_{2} \mathrm{PO}_{4}, 25 \mathrm{NaHCO}_{3}, 1.5 \mathrm{MgSO}_{4}, 11.0$ D-glucose, and $2.5 \mathrm{CaCl}_{2}$. Contractions were measured with an isometric Transducer (Grass Instruments, Quincy, MA) and recorded on a chart recorder (Gould Instruments, Cleveland, OH). Frequency-response curves $(1-40 \mathrm{~Hz})$ 


\section{A. $\beta 2$ targeting construct}

Figure 1. Gene targeting of the neuronal $\mathrm{nAChR} \beta 2$ and $\beta 4$ subunits. $A$, Partial genomic structure of the murine $\beta 2$ gene including the region from exons 1 to 6 (solid boxes) and the structure of the targeting vector are shown. The targeting vector contains $\mathrm{NeO}$ as a positive selectable marker. A homologous recombination event generated the deletion from exons 1 to 5 . The diagnostic probe at the $5^{\prime}$-flanking region is shown as an open box. $B$, Partial genomic structure of the murine $\beta 4$ gene and $\beta 4$-targeting vector are depicted with restriction enzyme sites and exons 5 and 6 (solid boxes). The targeting vector contains a puromycin resistance cassette (Puro) as a positive selectable marker and the Herpes simplex thymidine kinase gene $(T K)$ as a negative selectable marker to obtain a replacement mutation. The diagnostic flanking probe is indicated as an open box. In both $A$ and $B$ the restriction enzyme sites are as follows: E, Eco RI; H, HindIII; P, PstI; S, SacI; Sa, SalI; and X, $X h o I . C$, The three breeding schemes used to generate the mice studied are shown. Left, $\beta 2+/+\beta 4-/-$ were compared with $\beta 2-/-\beta 4-/-$ littermates. Center, Similarly, this breeding allowed comparison of $\beta 2-/-\beta 4+/+$ mice with $\beta 2-/-\beta 4-/-$ littermates. Right, Finally, in this breeding, $\beta 2+/+\beta 4-/-$ mice were compared with $\beta 2+/+\beta 4+/+$ (wild-type) littermates. $D$, Southern blot analysis identified the mice with the indicated genotypes using $\beta 2$ - and $\beta 4$-flanking probes as indicated in $A$ and $B$. E, Northern blot analysis of the expression of $\beta 2 \mathrm{mRNA}$ in the brains of $\beta 2+/+\beta 4+/+, \beta 2-/-\beta 4+/+, \beta 2+/+\beta 4-/-$, and $\beta 2-/-\beta 4-/-$ mice is shown. The probes are the rat cDNA of $\beta 2$ and a cDNA for the control gene glyceraldehyde-3phosphate dehydrogenase (gapdh). F, Reverse transcriptionPCR analysis of $\beta 4$ expression in the brains of $\beta 2+/+\beta 4+/+$, $\beta 2-/-\beta 4+1+, \beta 2+/+\beta 4-/-$, and $\beta 2-/-\beta 4-/-$ mice is shown. Reverse transcription was performed with the addition of reverse transcriptase $(R T)$ or absence of the enzyme $(-)$ as the negative control, followed by PCR with primers of either the $\beta 4$ gene or the hprt gene. The size of the PCR product is $176 \mathrm{bp}$ for the $\beta 4$ gene and $266 \mathrm{bp}$ for the hprt gene.

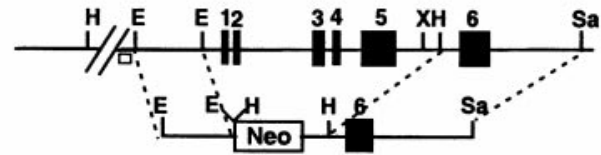

B. 34 targeting construct

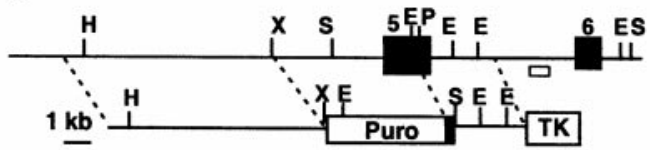

C.

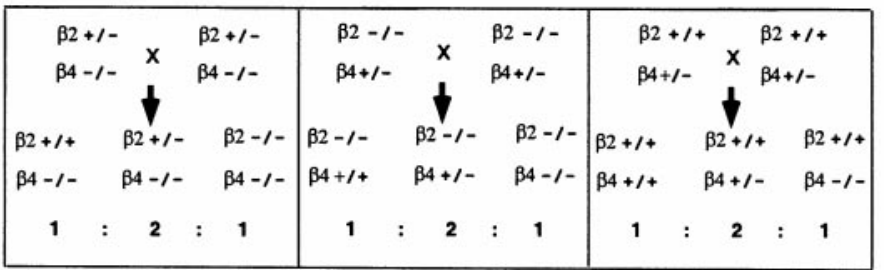

D.

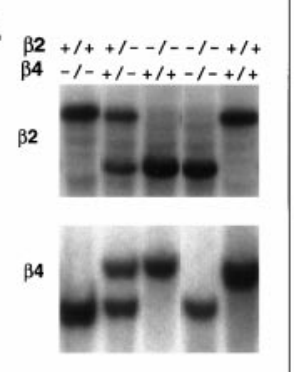

E.

$\beta_{2+1+-1-+1+-1-}$

$\beta 4+/++/+-/--1 /$

$\beta 2$

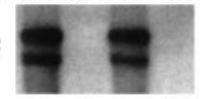

F.

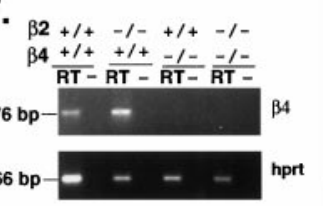

gapdh

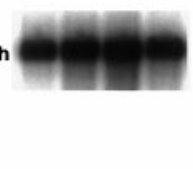

were elicited by stimulating the bladder strips for $5 \mathrm{sec}$ with pulses of 5 msec duration at supramaximal voltage $(50 \mathrm{~V})$ every $60 \mathrm{sec}$. Nicotine was added as a single dose $(0.1 \mathrm{~mm})$ directly to the organ bath and was washed out after a maximum contraction was recorded. To determine the relative response for each strip, we normalized the nicotine data to the contraction induced by the muscarinic agonist carbamylcholine $(\mathrm{CCH})$. A single dose of $0.1 \mathrm{~mm} \mathrm{CCH}$ was added after a $1 \mathrm{hr}$ interval with several changes of solution. Dose-response curves for $\mathrm{CCH}$ were constructed by adding cumulatively the drug from $0.1 \mu \mathrm{M}$ to $0.3 \mathrm{~mm}$. During the $\mathrm{CCH}$ experiments the bladder strips were preexposed to $20 \mu \mathrm{M}$ hexamethonium for $20 \mathrm{~min}$. Dose-response curves were fitted with a logistic equation to determine $\mathrm{EC}_{50}$ values.

Noninvasive measurement of intestinal peristalsis in newborn mice. Three- to five-day-old mice were separated from the mother and kept warm on an electrical blanket. After a $4 \mathrm{hr}$ fasting period the mice were administered by mouth $20 \mu \mathrm{l}$ of a blue- 1 color food dye (Adams Extract, Austin, TX) in 5\% glucose solution. The intraoral administration was performed with sterile Eppendorf microloaders (Eppendorf, Hamburg, Germany). Thirty minutes after the administration, mice were killed, and the stomach and intestines were carefully dissected. Intestinal propulsion was calculated as the percentage of the distance traveled by the colored solution per total length of the small intestine (from pylorus to ileocecal junction).

\section{RESULTS}

\section{Preparation of mice with null mutations for both the $\beta 2$ and $\beta 4$ subunits}

Mice deficient in the $\beta 2$ subunit were generated by replacing the $8 \mathrm{~kb}$ region containing exons 1 to 5 with Neo in ES cells followed by transmission to the germline (Fig. $1 A$ ). Southern blot analysis with HindIII and the $\beta 2$-flanking probe revealed a $6 \mathrm{~kb}$ fragment from the mutant allele in homozygous $(-/-)$ mice, a $12 \mathrm{~kb}$ fragment in the wild-type $(+/+)$ mice, and both fragments in heterozygous (+/-) mice. Similarly, mice lacking the $\beta 4 \mathrm{nAChR}$ subunit were prepared by introducing a $4.1 \mathrm{~kb}$ deletion including most of the exon 5-coding sequence in ES cells and further transmitted into the germline (Fig. $1 B$ ). Southern blot analysis using the $\beta 4$-flanking probe revealed a length change of the SacI fragment from $7.8 \mathrm{~kb}$ for the wild-type allele to $5.8 \mathrm{~kb}$ for the $\beta 4$ mutant allele. Three breeding schemes (Fig. $1 C$ ) were used to compare $\beta 2-/-\beta 4-/-$ with $\beta 2+/+\beta 4-/-$ littermates (Fig. $1 C$, left), $\beta 2-/-\beta 4-/-$ with $\beta 2-/-\beta 4+/+$ littermates (Fig. $1 C$, center), and $\beta 2+/+\beta 4-/-$ with $\beta 2+/+\beta 4+/+$ (wild-type) littermates (Fig. $1 C$, right). Examples of mice of various genotypes are shown by Southern blot in Figure $1 D$. The wild-type allele and mutant allele can also be distinguished by PCR using three oligonucleotides as described in Materials and Methods.

Expression of $\beta 2$ mRNA was not detectable by Northern blot in $\beta 2-/-$ mice, indicating that the $\beta 2$ mutation is a null allele (Fig. $1 E$ ). Reverse transcription-PCR analysis indicated that the expression of $\beta 4$ mRNA was not detectable in tissue from $\beta 4-/-$ mice; therefore, the $\beta 4$ mutation also is a null allele (Fig. $1 F$ ). The expression of either $\beta 2$ or $\beta 4$ was not noticeably affected in the mice with the null mutation of the other gene, and the expression of both genes was not detectable in mice with the double mutation $(\beta 2-/-\beta 4-/-$; Fig. $1 E, F)$.

\section{Retarded growth and postnatal lethality in $\boldsymbol{\beta} 2-/-\beta 4-/-$ mice}

The null mice for either the $\beta 2$ or $\beta 4 \mathrm{nAChR}$ subunits $(\beta 2-/$ $-\beta 4+/+$ and $\beta 2+/+\beta 4-/-)$ were viable and present in the expected ratio when generated from the mating of heterozygous 
A

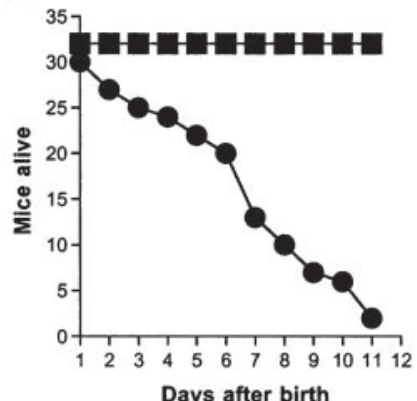

B
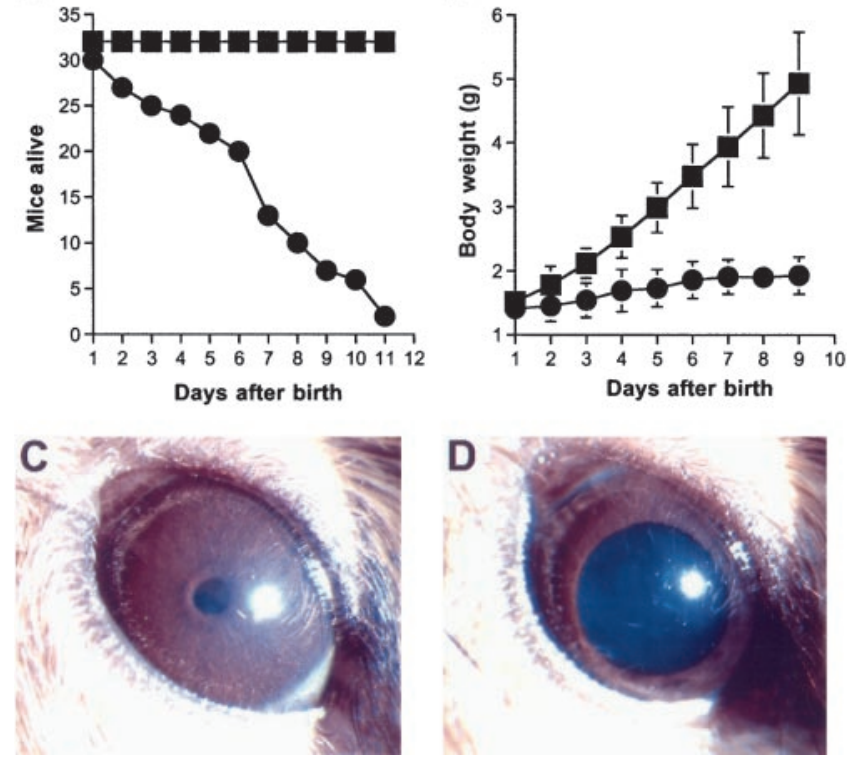

Figure 2. Phenotypic findings in mice lacking both $\beta 2$ and $\beta 4 \mathrm{nAChR}$ subunits. $A$, Survival curve of $30 \beta 2-/-\beta 4-/-$ mice $(\bullet)$ and 34 $\beta 2-/-\beta 4+/+$ mice ( $\square$ ) in the first $11 \mathrm{~d}$ after birth. The survival curve of the $\beta 2-/-\beta 4+/+$ mice did not differ from that of age-matched wild-type animals (data not shown). $B$, Body weight growth of $\beta 2-/-\beta 4-/-$ mice $(\mathbf{0} n=30$ at day 1 and $n=6$ at day 9) compared with that of $\beta 2-/-\beta 4+/+$ littermates $(\square ; n=34)$. The body weight of the $\beta 2-/-\beta 4+/+$ mice did not differ from that of age-matched $\beta 2+/+\beta 4-/-$ or wild-type animals (data not shown). Error bars represent the SD from the mean body weight for each group of animals. $C$, $D$, Comparison between the eye of a 16 -d-old $\beta 2-/-\beta 4+/+$ mouse $(C)$ and that of a $\beta 2-/-\beta 4-/-$ littermate $(D)$. The $\beta 2-/-\beta 4-/-$ mouse had widely dilated pupils that did not constrict in response to light. The eyes of $\beta 2+/+\beta 4-/-$ and $\beta 2-/-\beta 4+/+$ mice did not differ from those of wildtype animals.

mice (data not shown). The mice grew to normal size without showing any obvious physical or neurological deficits. The mice homozygous for both $\beta 2$ and $\beta 4$ mutations, generated by mating $\beta 2+/-\beta 4-/-$ mice (Fig. $1 C$, left) or $\beta 2-/-\beta 4+/-$ mice (Fig. $1 C$, center), were present in the expected ratio at birth. However, the $\beta 2-/-\beta 4-/-$ mice died over the first 3 weeks of life, and $<10 \%$ of the mice survived beyond $10 \mathrm{~d}$ after birth (Fig. 2A). Their growth was significantly impaired compared with that of the littermates containing two copies of the wild-type allele of either $\beta 2$ or $\beta 4$ (Fig. $2 B$ ). The double mutants also displayed retarded development, such as delayed hair growth and delayed opening and flattening of the ears after birth, and their eyelids remained closed after postnatal day 15 .

\section{Dilated ocular pupils in $\boldsymbol{\beta 2}-/-\boldsymbol{\beta} 4-/-$ mice}

In older $\beta 2-/-\beta 4-/-$ mice $(>18 \mathrm{~d})$, the palpebral fissures were noticeably smaller than those in controls or mice with a singlegene mutation, and the eyelids remained closed. Careful examination revealed that the ocular pupils were widely dilated compared with those in the other genotypes (Fig. 2C,D) and did not constrict in response to light when the lids were pried open. The wild-type mice as well as mice carrying at least one normal allele for $\beta 2$ or $\beta 4(\beta 2-/-\beta 4+/+$ or $\beta 2-/-\beta 4+/-$ and $\beta 2+/-\beta 4-/-$ or $\beta 2+/+\beta 4-/-)$ opened their eyes around postnatal day 15 and showed normal pupillary reflex to light.

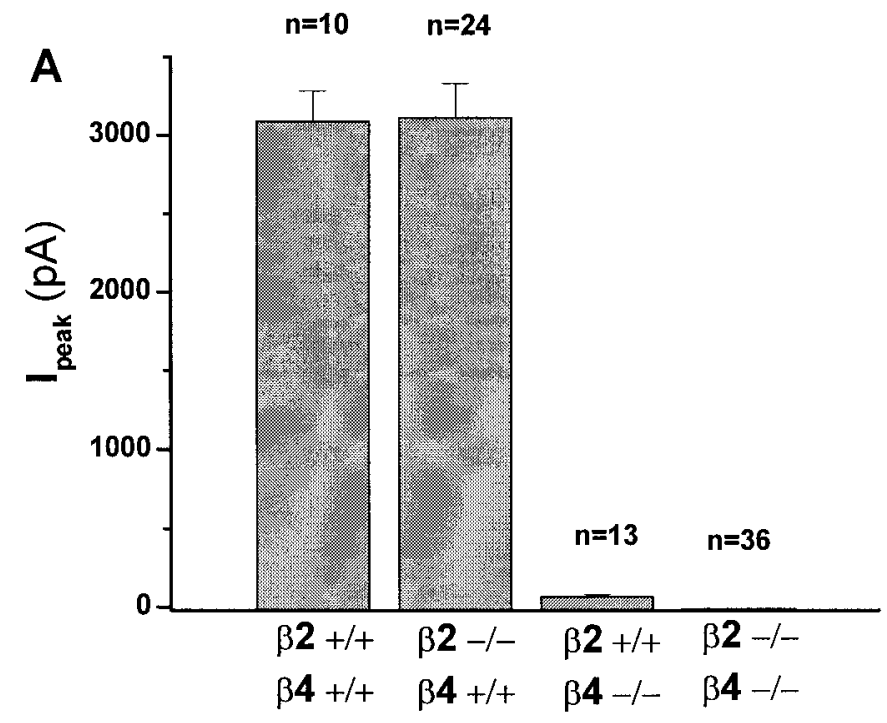

B
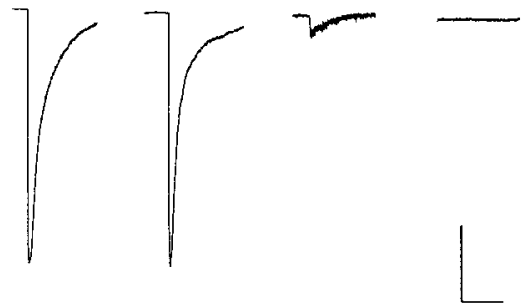

Figure 3. Comparison of nicotine-evoked currents from wild-type, $\beta 2-/-\beta 4+/+, \beta 2+/+\beta 4-/-$, and $\beta 2-/-\beta 4-/-$ superior cervical ganglia neurons. $A$, Vertical bars represent average peak currents in response to a $5 \mathrm{sec}$ pulse of nicotine $(300 \mu \mathrm{M})$. Nicotine induced a large-amplitude desensitizing current in $100 \%$ of $\beta 2+/+\beta 4+/+(I=3098 \pm 188 \mathrm{pA} ; n=$ $10)$ and $\beta 2-/-\beta 4+/+(I=3123 \pm 212 \mathrm{pA} ; n=24)$ neurons and a small-amplitude desensitizing current in $100 \%$ of $\beta 2+/+\beta 4-/-$ neurons $(I=73 \pm 7 \mathrm{pA} ; n=13)$. In contrast, there was no response to applied nicotine in any of the $\beta 2-1-\beta 4-1-$ neurons $(n=36)$. B, Traces are representative whole-cell currents from superior cervical ganglia neurons of each genotype tested and shown in $A$. Calibration: $\beta 2+/+\beta 4+/+$, $\beta 2-/-\beta 4+/+, 1000 \mathrm{nA}, 5 \mathrm{sec} ; \beta 2+/+\beta 4-/-, \beta 2-/-\beta 4-/-, 250 \mathrm{pA}, 5$ sec.

\section{Absence of ACh-activated nAChR currents in the superior cervical ganglion neurons of $\boldsymbol{\beta} 2-/-\boldsymbol{\beta} 4-/-$ mice}

To test whether the genetic deletion of $\beta 2$ and/or $\beta 4$ subunits altered the nAChR-mediated responses of sympathetic ganglion neurons, we examined the macroscopic currents elicited by applied nicotine. Neurons were dispersed from the superior cervical ganglia (SCG) of individual neonatal pups and maintained in vitro as described in Materials and Methods. Application of maximal concentrations of nicotine $(300 \mu \mathrm{M})$ elicited robust inward currents in all neurons from wild-type mice $\left(I_{\text {avg }}=3098 \pm 188 \mathrm{pA}\right.$; $n=10)$, whereas there was no detectable response to applied nicotine in the $\beta 2-/-\beta 4-/-$ mice at any concentration tested (ranging from $10 \mu \mathrm{M}$ to $3 \mathrm{~mm} ; n=36,5$ animals; Fig. $3 A$ ). ACh $(300 \mu \mathrm{M})$ and cytisine $(300 \mu \mathrm{M})$ were equally ineffective in eliciting currents from these mice ( $n=6$; data not shown). Analysis of the nicotine-evoked macroscopic currents recorded in $\beta 2+/+\beta 4-/-$ or in $\beta 2-/-\beta 4+/+$ mice indicated that both $\beta$ subunits can participate in functional nAChRs in mouse SCG (Fig. $3 B$ ). However, comparison of the magnitude of the nicotinic 

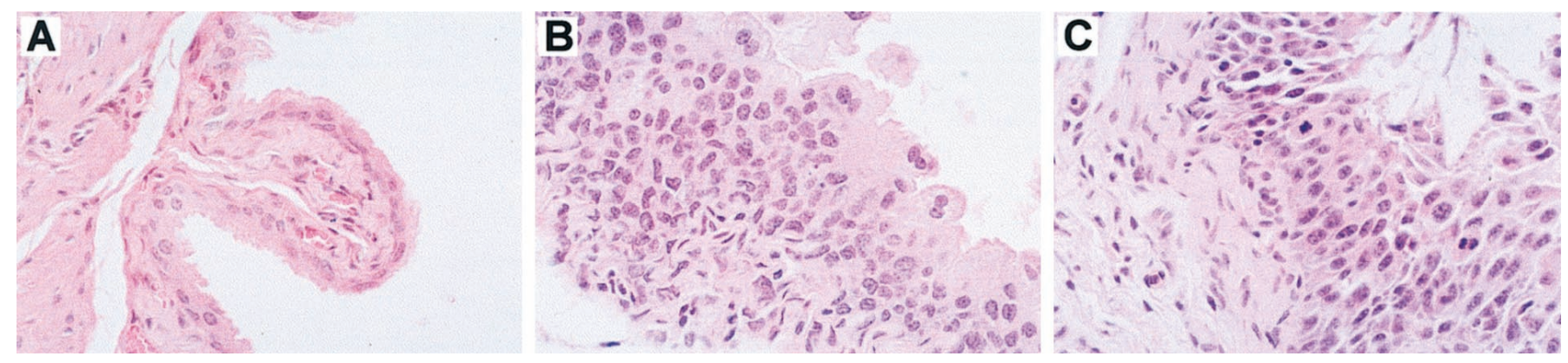

Figure 4. Altered bladder epithelium in $\beta 2-/-\beta 4-/-$ mice. $A$, Microscopy of a $\beta 2+/+\beta 4+/+$ bladder wall with epithelium and underlying muscle. The epithelium is composed of several layers of regular cells. H\&E staining, $400 \times$. B, Bladder epithelium of a $\beta 2-/-\beta 4-/-$ mouse that exhibits dysplasia. The number of epithelial cells is increased, and the cells are irregularly arranged. Some of the cells have decreased amounts of cytoplasm with an altered nuclear-to-cytoplasmic ratio. H\&E staining, $400 \times$. C, Bladder epithelium and underlying smooth muscle from an $\alpha 3-/-$ mouse. The epithelium is dysplastic with an increased number of cells, which are irregularly arranged. Some cells show hyperchromatic nuclei and have decreased amounts of cytoplasm. Two cells exhibit mitotic figures. H\&E staining, 400×.

responses in $\beta 2+/+\beta 4-/-$ versus $\beta 2-/-\beta 4+/+$ mice suggests that $\beta 4$-containing $\mathrm{nAChRs}$ underlie a significant portion of the wild-type, nicotine-evoked currents. Thus the average peak of nicotine-gated macroscopic currents in $\beta 4$-deficient neurons was $2 \%$ that of wild-type or $\beta 2$-deficient neurons $\left[\beta 2+/+\beta 4-/-\left(I_{\text {avg }}\right.\right.$ $=73 \pm 7 \mathrm{pA})$ vs $\beta 2-/-\beta 4+/+\left(I_{\mathrm{avg}}=3123 \pm 212 \mathrm{pA}\right) ; n=13$ and 24 , respectively).

\section{Hypoperistalsis in $\beta 2-/-\beta 4-/-$ mice}

We examined intestinal propulsion in $\beta 2-/-\beta 4-/-$ mice and their littermate controls by administration of blue-1 color food. Thirty minutes after oral administration, the blue-colored solution had traveled $45.1 \pm 2.1 \%( \pm$ SEM $)$ and $36.9 \pm 4.2 \%$ along the intestinal tract of $\beta 2-/-\beta 4+/+(n=23)$ and $\beta 2-/-\beta 4-/-$ $(n=13)$ mice, respectively $(p<0.05)$. The length of the small intestine, from the pylorus to the ileocecal valve, was $12.3 \pm 0.4$ $\mathrm{cm}( \pm \mathrm{SEM})$ for the $\beta 2-/-\beta 4+/+(n=23)$ mice and $10.2 \pm 0.4$ $\mathrm{cm}$ for the $\beta 2-/-\beta 4-/-(n=13)$ mice. Although significantly different, the shorter intestinal length in the $\beta 2-/-\beta 4-/-$ mice was in accordance with their smaller size. Intestinal motility in wild-type animals did not differ from that of the $\beta 2-/-\beta 4+/+$ mice.

\section{Histochemical analysis of the double-mutant mice}

Gross and microscopic examination of heart, lungs, gastrointestinal tract, liver, spleen, gonads, kidney, adrenal glands, pancreas, and skeletal muscle from each of the four groups of animals studied showed no consistent abnormality. The cerebral cortex, hippocampus, basal ganglia, brain stem, and cerebellum also revealed no abnormalities using $\mathrm{H} \& \mathrm{E}$ and anti-GFAP staining. The bladders of seven out of seven $\beta 2-/-\beta 4-/-$ mice (ages, 4-24 d) were abnormal (Fig. 4B). Three bladders were dilated, and all had abnormalities of the mucosa consisting of increased thickness of the mucosal layer (focal or diffuse), evidence of mitotic activity in four, and disorganization or dysplastic change in three. One bladder showed mucosal calcification. Intramural nerves were identified in all of the bladders using antineurofilament antibodies. These alterations were less severe but resembled those seen in bladders of the $\alpha 3-/-$ mice $(\mathrm{Xu}$ et al., $1999)$, as illustrated in Figure $4 C$. Bladders from $\beta 2+/+\beta 4-/-$ mice revealed focal hyperplasia or dysplasia in three out of four animals and mitotic activity in two out of four animals. In five wild-type mice (ages, 4-33 d), bladder mucosa was normal in three, one showed focal thickening, and one showed a single mitotic figure (Fig. 4A). In $\beta 2-/-\beta 4+/+$ mice (ages, $3-41 \mathrm{~d}$ ), the mucosa showed focal thickening without mitosis in five out of six animals. Nerves were present in all of the bladder walls as indicated by positive staining with anti-neurofilament $\mathrm{mAb}$.

\section{Lack of bladder contractility in $\beta 4-/-$ and $\boldsymbol{\beta 2}-/-\boldsymbol{\beta} 4-/-$ mice}

Similar to the mice deficient in the $\alpha 3 \mathrm{nAChR}$ subunit (Xu et al., 1999), the $\beta 2-/-\beta 4-/-$ mice displayed distended urinary bladders and dribbling urination. Their urine became infected with Gram-negative and Gram-positive bacteria and often contained stones of calcium phosphate and magnesium phosphate as described for the $\alpha 3$-deficient mice (Xu et al., 1999). Blood chemistry measurements were performed to determine glucose, electrolytes, phosphate, calcium, urea nitrogen, and creatinine, and no consistent differences were found between control and singleor double-mutant mice. Urine chemistries included glucose, electrolytes, phosphate, calcium, and creatinine and did not reveal significant differences among the groups studied.

To study functional responses mediated by the intramural postganglionic parasympathetic innervation, we measured the contraction to $0.1 \mathrm{~mm}$ nicotine in bladder strips from wild-type, $\beta 2+/+\beta 4-/-, \beta 2-/-\beta 4+/+$, and $\beta 2-/-\beta 4-/-$ mice (Fig. 5A). The responses of $\beta 2-/-\beta 4+/+$ mice were superimposable with those of their wild-type littermate controls. In the $\beta 2-/-\beta 4-/-$ mice, similar to the mice lacking the $\alpha 3$ subunit, the contractility to nicotine was impaired. Surprisingly, bladder responses were also significantly reduced in the $\beta 2+/+\beta 4-/-$ mice, despite the absence of bladder distension and urine retention. Nicotine responses in wild-type mice were $44 \%$ of the contraction elicited by direct muscarinic stimulation of the bladder smooth muscle with $\mathrm{CCH}$. Nicotine responses in the $\beta 2+/+\beta 4-/-$ mice were only $3 \%$ of the contraction in response to $0.1 \mathrm{~mm} \mathrm{CCH}$.

To decipher the mechanisms of bladder dysf unction further, we analyzed bladder strips for contractile responses to $\mathrm{CCH}$, a stable $\mathrm{ACh}$ analog. Figure $5 B$ shows the contractile responses of bladder smooth muscle strips to $\mathrm{CCH}$. In the $\beta 2-/-\beta 4+/+$ mice, when neuronal nAChRs were blocked by preincubation with $20 \mu \mathrm{M}$ hexamethonium, the concentration-response curves for $\mathrm{CCH}$ were superimposable with those of the wild-type mice. In the same experimental conditions, we observed a leftward shift of the $\mathrm{CCH}$ concentration-response curves for both the $\beta 2+/+\beta 4-/-$ and the $\beta 2-/-\beta 4-/-$ mutants. The latter results suggest that the ability of bladder smooth muscles to respond to muscarinic receptor stimulation is preserved in the mutant mice. Muscarinic 
A

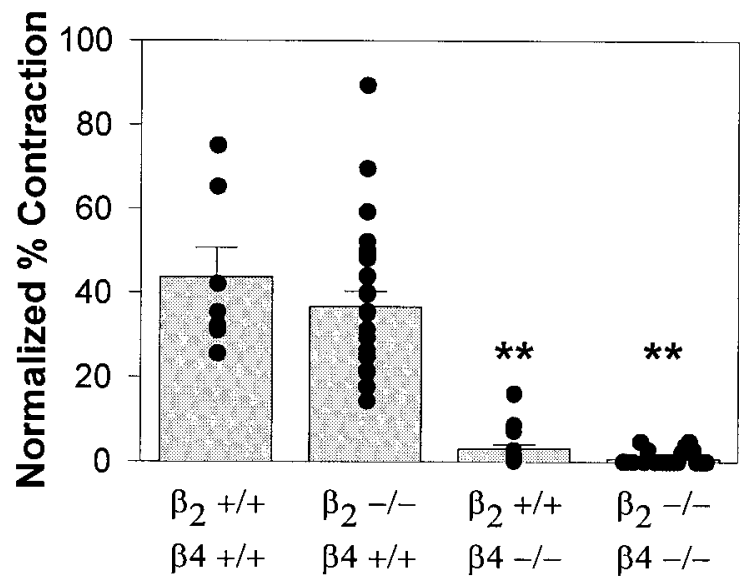

B

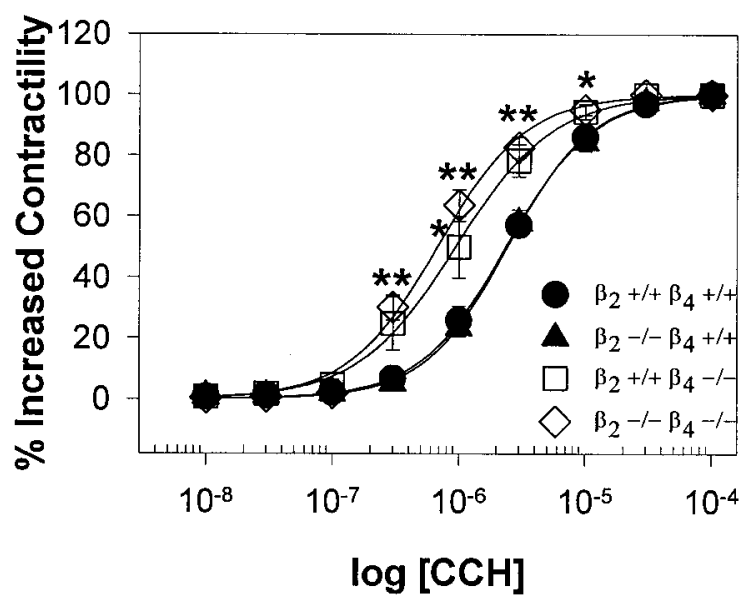

C

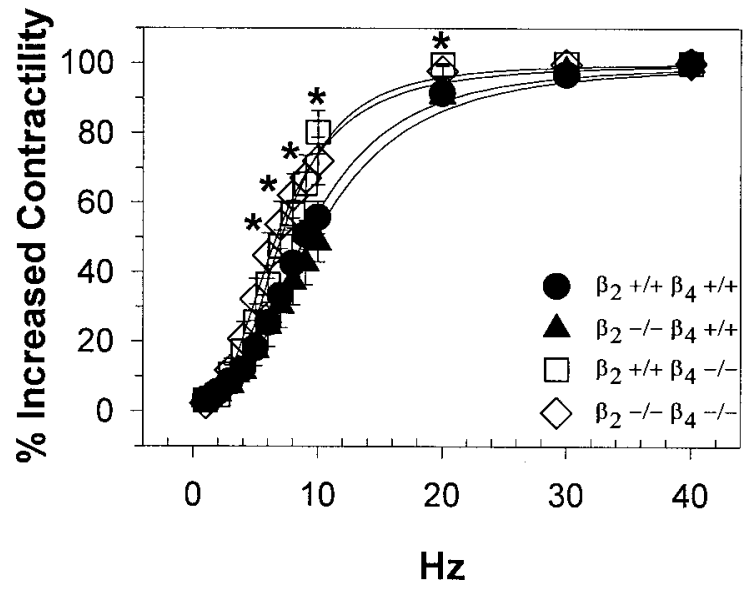

Figure 5. Reduced bladder contraction in response to nicotine in $\beta 2+/+\beta 4-/-$ and $\beta 2-/-\beta 4-/-$ mice. $A$, Responses to nicotine in $\beta 2+/+\beta 4+/+(n=4), \beta 2-/-\beta 4+/+(n=18), \beta 2+/+\beta 4-/-(n=17)$, and $\beta 2-/-\beta 4-/-(n=12)$ mice are shown. Data represent the contractile response to nicotine as a percentage of that to $\mathrm{CCH}( \pm \mathrm{SEM} ; * * p<$ 0.01). $B$, Bladder contractions in response to $\mathrm{CCH}$ were superimposable in $\beta 2+/+\beta 4+/+(\boldsymbol{O})$ and $\beta 2-/-\beta 4+/+(\boldsymbol{\Delta})$ mice and were similar in $\beta 2+/+\beta 4-/-(\square)$ and $\beta 2-/-\beta 4-/-(\diamond)$ mice. The contractility responses of both $\beta 2+/+\beta 4-/-$ and $\beta 2-/-\beta 4-/-$ mice were significantly receptor supersensitivity, suggested by the leftward shift of the concentration-response curves, might be a consequence of reduced ACh release onto the bladder smooth muscle in the $\beta 4$ deficient mice.

We also tested whether neurotransmitter release could be elicited in the mutant mice by exposing bladder strips to electric field stimulation. Figure $5 C$ shows that frequency-response curves were similar for $\beta 2-/-\beta 4+/+$ and wild-type mice, whereas those for $\beta 2+/+\beta 4-/-$ and $\beta 2-/-\beta 4-/-$ mice were shifted to the left. These results, together with the histochemistry results showing normal intramural innervation of the bladder, suggest that bladder innervation in $\beta 2+/+\beta 4-/-$ and $\beta 2-/-\beta 4-/-$ mutants is normal and that neurotransmitters can be released via mechanisms that bypass nAChR stimulation.

\section{DISCUSSION}

The simultaneous absence of the $\beta 2$ and the $\beta 4 \mathrm{nAChR}$ subunits produces severe autonomic dysfunction with megacystis, hypoperistalsis, mydriasis, and palpebral ptosis being among the most obvious phenotypic characteristics. In addition, the rate of perinatal mortality is highly increased, and in the surviving mice, the postnatal growth is retarded.

The ptosis of the upper eyelid in $\beta 2-/-\beta 4-/-$ mice might reflect developmental delay and poor growth or might be explained by the absence of sympathetic inputs to the eyelid muscle innervated by postganglionic sympathetic fibers from the superior cervical ganglion (Yamashita and Honjin, 1982). The absence of ACh-elicited currents in $\beta 2-/-\beta 4-/-$ SCG cells suggests that synaptic transmission may be interrupted at the level of the SCG (Selyanko, 1995), thereby preventing norepinephrine release onto the eyelid muscle. Because mice lacking the $\alpha 3$ subunit also manifest palpebral ptosis and have anomalous nAChR currents in SCG neurons (Xu et al., 1999), we conclude that the majority of SCG nAChRs contain combinations of $\alpha 3, \beta 2$, and $\beta 4$ subunits, with $\alpha 3 \beta 4$ possibly representing the majority among these nAChRs. The present studies could not determine what subunits in addition to $\alpha 3, \beta 2$, and $\beta 4$ may participate in functional SCG nAChRs, but $\alpha 5$ is a possible candidate (Covernton et al., 1994; Sivilotti et al., 1997). We also cannot exclude the participation of central mechanisms of the palpebral phenotype of the double mutants because $\beta 2$ and $\beta 4$ are also expressed in the CNS (Duvoisin et al., 1989; Wada et al., 1989; Boulter et al., 1990; Dineley-Miller and Patrick, 1992; Zoli et al., 1998).

The lack of the pupillary reflex to light in the $\beta 2-/-\beta 4-/-$ mice indicates dysfunction of the parasympathetic innervation of the eye. The pupillary sphincter controls pupil diameter and is innervated by parasympathetic postganglionic fibers departing from the ciliary ganglion (Yamashita et al., 1984). Although we have not recorded ACh-elicited currents from ciliary ganglion neurons, we hypothesize that mydriasis may arise from impaired synaptic transmission in the ciliary ganglion. As discussed for the eyelid, we cannot exclude the participation of more central mechanisms.

The most evident phenotypic finding in the $\beta 2-/-\beta 4-/-$ mice

$$
\leftarrow
$$

different from those of $\beta 2+/+\beta 4+/+$ and $\beta 2-/-\beta 4+/+$ mice $(* * p<$ $0.01 ; * p<0.05)$. C. Bladder contractions in response to field stimulation were similar for $\beta 2+/+\beta 4+/+(\bullet)$ and $\beta 2-/-\beta 4+/+(\boldsymbol{\Delta})$ mice and for $\beta 2+/+\beta 4-/-(\square)$ and $\beta 2-/-\beta 4-/-(\diamond)$ mice. The contractility responses of $\beta 2+/+\beta 4-/-$ and $\beta 2-/-\beta 4-/-$ mice were significantly different from those of $\beta 2+/+\beta 4+/+$ and $\beta 2-/-\beta 4+/+$ mice $\left({ }^{*} p<0.05\right)$. 
was the enlarged bladder with dribbling urination, urinary infection, and stone formation. The data presented are consistent with a severe reduction of bladder contractility as the cause for megacystis and the other urinary symptoms. In rodents, most efferent innervation to the bladder musculature originates from the pelvic ganglion (Ekstrom and Elmer, 1980). However, some efferent preganglionic fibers pass through the pelvic ganglion and synapse with intramural ganglion cells found within the bladder wall. We studied nicotine responses in bladder strips, which contain intramural parasympathetic ganglionic neurons. In these experimental conditions, contractile responses to nicotine were absent in $\beta 2-/-\beta 4-/-$ and significantly reduced in $\beta 2+/+\beta 4-/-$ but were normal in $\beta 2-/-\beta 4+/+$ mice. We have shown previously that bladder strips from $\alpha 3-/-$ mice also do not contract in response to nicotine. These data are consistent with intramural parasympathetic ganglion cells predominantly expressing $\alpha 3 \beta 4$ containing nAChRs. In vivo, however, bladder distension and anomalous micturition develop in the $\alpha 3-/-$ and the $\beta 2-/-\beta 4-/-$ mutants but not in mice lacking the $\beta 4$ subunit only. Neuronal nAChRs expressed in pelvic ganglion neurons may contain combinations of $\alpha 3 \beta 4, \alpha 3 \beta 2$, and $\alpha 3 \beta 2 \beta 4$ subunits. When only one of the two $\beta$ subunits is absent, nAChRs containing the remaining $\beta$ subunit are sufficient to ensure enough $\mathrm{ACh}$ release onto the bladder smooth muscle to sustain micturition.

The experimental paradigm we used allowed us to concentrate on the spinal portion of the micturition reflex. Several studies indicate that in newborn animals, micturition occurs in response to a short-latency somatovesical spinal reflex activated when the mother licks the perineal area (deGroat and Booth, 1980). In particular, such a mechanism is essential for survival of pups $<5$ d old (deGroat and Booth, 1980; Henning, 1981; Sato et al., 1983). Thereafter a supraspinal reflex develops that subserves micturition in normal adult animals (deGroat and Booth, 1980; Sato et al., 1983). Because we have studied animals between postnatal days 3 and 7, we can assume that the neural pathways mediating the supraspinal component of the micturition reflex do not contribute to the phenotype of the mutant mice studied. In addition, despite the expression of $\beta 2 \mathrm{nAChR}$ subunits in the pontine reticular formation where the CNS micturition center resides (Wada et al., 1989), both adult and newborn $\beta 2-/-$ mice do not develop bladder dysfunction.

Comparison of the $\beta 2-/-\beta 4+/+, \quad \beta 2+/+\beta 4-/-, \quad$ and $\beta 2-/-\beta 4-/-$ mice provides a particularly instructive view into concepts of redundancy and genetic principles. There is at times an apparent conflict arising from the fact that homozygous null mice for many individual genes do not show an obvious phenotype, suggesting there is some redundancy or lack of essentiality for these genes. However, these genes are often evolutionarily conserved between mouse and human, suggesting that they are not dispensable in the natural setting of evolutionary selection. The $\beta 2+/+\beta 4-/-$ mice appear not to have an obvious phenotype in terms of survival and growth, but the $\beta 2-/-\beta 4-/-$ mice have a very severe phenotype, implying there is some redundancy or lack of essentiality for the $\beta 4$ gene. In contrast, examination of the data from bladder contractility and ion channel function in the superior cervical ganglion demonstrates that there are profound physiological deficits in the $\beta 4-/-$ mice despite their superficially normal growth and survival. This provides an elegant insight into what may be a frequent circumstance in the gene-targeting methodology in the mouse in which the apparent redundancy is superficial and more sophisticated testing in a natural setting as well as other physiological studies might dem- onstrate that the redundancy is more apparent than real. The data from the mice reported here demonstrate that one can think about a partial and quite low level of function through redundancy as being similar to residual activity for the primary gene product. This limited redundancy may often preserve normal physiology when involving enzymes and pathways as described by Kacser and Burns (1981).

The multiorgan autonomic dysfunction described here for the $\beta 2-/-\beta 4-/-$ mice resembles that described previously in mice deficient for the $\alpha 3$ subunit (Xu et al., 1999). Overall the symptoms observed in the mice are similar to those of the human autosomal recessive megacystis-microcolon-intestinal hypoperistalsis syndrome (MMIHS) (Anneren et al., 1991). The data presented are also instructive in considering possible parallels with the human MMIHS disorder. As we speculated previously, mutations in the $\alpha 3 \mathrm{nAChR}$ subunit might be the basis of this condition in humans. However, the data for the $\beta 4-/-$ mice make it clear that the human disorder might alternatively be caused by loss-of-function mutations in the $\beta 4$ subunit. The prune belly syndrome would be another disorder of particular interest regarding the possibility of mutations in various $\mathrm{nAChR}$ subunits. This syndrome frequently reflects megacystis in utero resolving by the time of birth, and there are some similarities between prune belly syndrome and MMIHS (Oliveira et al., 1983). Similarly, other human disorders such as congenital mydriasis, intestinal hypoperistalsis, or pseudo-obstruction or other forms of autonomic dysfunction might be caused by varying deficits in neuronal nAChRs.

In conclusion, we have shown that the simultaneous absence of the $\beta 2$ and the $\beta 4$ subunits alters the autonomic control of several peripheral organs and affects survival and growth. The lack of overt phenotypes in mice lacking either $\beta$ subunit indicates a partial redundancy between $\beta 2$ and $\beta 4$. It is anticipated that the autonomic dysfunction observed in the $\beta 2-/-\beta 4-/-$ mice affects other organ systems such as the cardiovascular system. Because of the high perinatal mortality, investigation of possible CNS dysfunction in the $\beta 2-/-\beta 4-/-$ mice will be feasible only with conditional mutations restricted to the CNS. The $\beta 2-/-$ and the $\beta 4-/-$ single-mutant mice are readily available for behavioral studies in basal conditions as well as during nicotine administration.

\section{REFERENCES}

Anand R, Conroy WG, Schoepfer R, Whiting P, Lindstrom J (1991) Neuronal nicotinic acetylcholine receptors expressed in Xenopus oocytes have a pentameric quaternary structure. J Biol Chem 266:11192-11198.

Anneren G, Meurling S, Olsen L (1991) Megacystis-microcolonintestinal hypoperistalsis syndrome (MMIHS), an autosomal recessive disorder: clinical reports and review of the literature. Am J Med Genet 41:251-254.

Boulter J, O'Shea-Greenfield A, Duvoisin RM, Connolly JG, Wada E, Jensen A, Gardner PD, Ballivet M, Deneris ES, McKinnon D, et al. (1990) Alpha 3, alpha 5, and beta 4: three members of the rat neuronal nicotinic acetylcholine receptor-related gene family form a gene cluster. J Biol Chem 265:4472-4482.

Bradley A (1987) Teratocarcinomas and embryonic stem cells; a practical approach. Oxford: IRL.

Colquhoun LM, Patrick JW (1997) Alpha3, beta2, and beta4 form heterotrimeric neuronal nicotinic acetylcholine receptors in Xenopus oocytes. J Neurochem 69:2355-2362.

Cooper E, Couturier S, Ballivet M (1991) Pentameric structure and subunit stoichiometry of a neuronal nicotinic acetylcholine receptor. Nature 350:235-238.

Covernton PJ, Kojima H, Sivilotti LG, Gibb AJ, Colquhoun D (1994) Comparison of neuronal nicotinic receptors in rat sympathetic neu- 
rones with subunit pairs expressed in Xenopus oocytes. J Physiol (Lond) 481:27-34.

deGroat WC, Booth AM (1980) Physiology of the urinary bladder and urethra. Ann Intern Med 92:312-315.

Dineley-Miller K, Patrick J (1992) Gene transcripts for the nicotinic acetylcholine receptor subunit, beta4, are distributed in multiple areas of the rat central nervous system. Brain Res Mol Brain Res 16:339-344.

Duvoisin RM, Deneris ES, Patrick J, Heinemann S (1989) The functional diversity of the neuronal nicotinic acetylcholine receptors is increased by a novel subunit: beta 4. Neuron 3:487-496.

Ekstrom J, Elmer M (1980) Compensatory increase of responses to nerve stimulation of the partially denervated rat urinary bladder. Acta Physiol Scand 110:21-29.

Flores CM, Hulihan-Giblin BA, Hornby PJ, Lumpkin MD, Kellar KJ (1992) Partial characterization of a neurotransmitter pathway regulating the in vivo release of prolactin. Neuroendocrinology 55:519-528.

Fucile S, Matter JM, Erkman L, Ragozzino D, Barabino B, Grassi F, Alema S, Ballivet M, Eusebi F (1998) The neuronal alpha6 subunit forms functional heteromeric acetylcholine receptors in human transfected cells. Eur J Neurosci 10:172-178.

Gerzanich V, Kuryatov A, Anand R, Lindstrom J (1997) "Orphan" alpha6 nicotinic AChR subunit can form a functional heteromeric acetylcholine receptor. Mol Pharmacol 51:320-327.

Goldman D, Deneris E, Luyten W, Kochhar A, Patrick J, Heinemann S (1987) Members of a nicotinic acetylcholine receptor gene family are expressed in different regions of the mammalian central nervous system. Cell 48:965-973.

Henning SJ (1981) Postnatal development: coordination of feeding, digestion, and metabolism. Am J Physiol 241:G199-G214.

Kacser H, Burns JA (1981) The molecular basis of dominance. Genetics 97:639-689.

Listerud M, Brussaard AB, Devay P, Colman DR, Role LW (1991) Functional contribution of neuronal AChR subunits revealed by antisense oligonucleotides. Science 254:1518-1521.

Mandelzys A, Pie B, Deneris ES, Cooper E (1994) The developmental increase in ACh current densities on rat sympathetic neurons correlates with changes in nicotinic ACh receptor alpha-subunit gene expression and occurs independent of innervation. J Neurosci 14:2357-2364.

Marubio LM, del Mar Arroyo-Jimenez M, Cordero-Erausquin M, Lena C, Le Novere N, de Kerchove d'Exaerde A, Huchet M, Damaj MI, Changeux JP (1999) Reduced antinociception in mice lacking neuronal nicotinic receptor subunits. Nature 398:805-810.

McGehee DS, Role LW (1995) Physiological diversity of nicotinic acetylcholine receptors expressed by vertebrate neurons. Annu Rev Physiol 57:521-546.

Morris BJ, Hicks AA, Wisden W, Darlison MG, Hunt SP, Barnard EA (1990) Distinct regional expression of nicotinic acetylcholine receptor genes in chick brain. Brain Res Mol Brain Res 7:305-315.

Oliveira G, Boechat MI, Ferreira MA (1983) Megacystis-microcolonintestinal hypoperistalsis syndrome in a newborn girl whose brother had prune belly syndrome: common pathogenesis? Pediatr Radiol 13:294-296.

Picciotto MR, Zoli M, Lena C, Bessis A, Lallemand Y, LeNovere N, Vincent P, Pich EM, Brulet P, Changeux JP (1995) Abnormal avoidance learning in mice lacking functional high-affinity nicotine receptor in the brain. Nature 374:65-67.
Poth K, Nutter TJ, Cuevas J, Parker MJ, Adams DJ, Luetje CW (1997) Heterogeneity of nicotinic receptors class and subunit mRNA expression among individual parasympathetic neurons from rat intracardiac ganglia. J Neurosci 17:586-596.

Ramirez-Latorre J, Yu CR, Qu X, Perin F, Karlin A, Role L (1996) Functional contributions of alpha5 subunit to neuronal acetylcholine receptor channels. Nature 380:347-351.

Ramirez-Solis R, Liu P, Bradley A (1995) Chromosome engineering in mice. Nature 378:720-724.

Rust G, Burgunder JM, Lauterburg TE, Cachelin AB (1994) Expression of neuronal nicotinic acetylcholine receptor subunit genes in the rat autonomic nervous system. Eur J Neurosci 6:478-485.

Sargent PB (1993) The diversity of neuronal nicotinic acetylcholine receptors. Annu Rev Neurosci 16:403-443.

Sato A, Sato Y, Schmidt RF, Torigata Y (1983) Somatovesical reflexes in chronic spinal rats. J Auton Nerv Syst 7:351-362.

Selyanko AA (1995) Properties of nicotinic postsynaptic receptor channels in ganglia. In: Autonomic ganglia (McLachlan EM, ed), pp 213258. Sidney, Australia: Harwood.

Sivilotti LG, McNeil DK, Lewis TM, Nassar MA, Schoepfer R, Colquhoun D (1997) Recombinant nicotinic receptors, expressed in Xenopus oocytes, do not resemble native rat sympathetic ganglion receptors in single-channel behaviour. J Physiol (Lond) 500:123-138.

Wada E, Wada K, Boulter J, Deneris E, Heinemann S, Patrick J, Swanson LW (1989) Distribution of alpha 2, alpha 3, alpha 4, and beta 2 neuronal nicotinic receptor subunit mRNAs in the central nervous system: a hybridization histochemical study in the rat. J Comp Neurol 284:314-335.

Wang F, Gerzanich V, Wells GB, Anand R, Peng X, Keyser K, Lindstrom J (1996) Assembly of human neuronal nicotinic receptor alpha5 subunits with alpha3, beta2, and beta4 subunits. J Biol Chem 271:17656-17665.

$\mathrm{Xu} \mathrm{W}$, Gelber S, Orr-Urtreger A, Armstrong D, Lewis RA, Ou C-N, Patrick J, Role LW, De Biasi M, Beaudet AL (1999) Megacystis, mydriasis, and ion channel defect in mice lacking the $\alpha 3$ neuronal nicotinic acetylcholine receptor. Proc Natl Acad Sci USA 96:5746-5751.

Yamashita T, Honjin R (1982) Fine structure, origin, and distribution density of the autonomic nerve endings in the tarsal muscle in the eyelid of the mouse. Cell Tissue Res 222:459-465.

Yamashita T, Takahashi A, Honjin R (1984) Fine structure, origin, and distribution density of the autonomic nerve endings in the sphincter and dilator muscles of the pupil of the mouse. Okajimas Folia Anat Jpn 61:173-181.

Zhang X, Liu C, Miao H, Gong ZH, Nordberg A (1998) Postnatal changes of nicotinic acetylcholine receptor alpha 2, alpha 3, alpha 4, alpha 7 and beta 2 subunits genes expression in rat brain. Int $\mathbf{J}$ Dev Neurosci 16:507-518.

Zoli M, Lena C, Picciotto MR, Changeux JP (1998) Identification of four classes of brain nicotinic receptors using beta2 mutant mice. J Neurosci 18:4461-4472.

Zoli M, Picciotto MR, Ferrari R, Cocchi D, Changeux JP (1999) Increased neurodegeneration during ageing in mice lacking high-affinity nicotine receptors. EMBO J 18:1235-1244. 